\title{
Pemberian Sludge Palm Oil (SPO) dan Penggunaan Metode Tanam Hazton, Sri dan Konvensional terhadap Produksi dan Hasil Padi
}

\section{Giving Sludge Palm Oil (SPO) and Use of Hazton, Sri and Conventional Planting Methods on Rice Production and Outcome}

\author{
Emilia Farida Budi Handayani" ${ }^{\# 1}$ Pamela $^{\# 1}$ \\ ${ }^{\#}$ Politeknik Tonggak Equator \\ Jalan AR Hakim No 106 \\ ${ }^{1}$ polteq_pontianak@yahoo.com
}

\begin{abstract}
Food crop development programe of West Kalimantan in 2016 aimed to increase either the application of Hazton cropping technique for about $\mathbf{4 4 . 5 0 0}$ hectares or organic rice planting for about 160 hectares. Hazton is a newly intorduced cropping technique so that most of farmers have not applied it yet. Farmers had a trouble to apply organic farming because lack of organic substances were available. Sludge palm oil is one of palm oil factory's waste that available abundantly in West Kalimantan, it offers potential for being organic fertilizer. This research is aimed to determine the effective dosage of sludge palm oil combined with some of cropping techniques, on growth and yield of rice plants. It used factorial randomized block design consisted of two factors, they were sludge palm oil dosage with 5 treatments; $0,10,20,30$, and 40 ton.ha ${ }^{-1}$, and cropping technique with 3 treatments; Hazton, SRI, and conventional system. Each treatment was repeated for 5 times. The results indicated that the interaction between sludge palm oil and cropping techniques application effected significantly on plant height, dry weight of rice, and 1000 seed weight. While the number of tillers per hill, number of panicles, and wet weight of stem were not effected significantly.
\end{abstract}

Key words: sludge palm oil, Hazton, SRI, konvensional

\section{PENDAhuluan}

Kebutuhan padi akan terus meningkat seiring dengan proyeksi laju pertambahan penduduk. Laju pertumbuhan jumlah penduduk masih lebih tinggi bila dibandingkan dengan laju pertumbuhan produksi padi nasional, di sisi lain luas baku lahan sawah dan kualitasnya cenderung menurun akibat konservasi lahan dan faktor faktor lainnya. Menyadari fungsi dan peran penting padi tersebut, maka pemerintah terus berupaya untuk mewujudkan peningkatan produksi padi. Pada tahun 2016 selain difokuskan pada kegiatan peningkatan produktivitas (intensifikasi) juga dirancang kegiatan perluasan areal tanam (ekstensifikasi).

Alokasi kegiatan pengembangan tanaman pangan APBN tahun 2016 Provinsi Kalimantan
Barat terdiri dari kegiatan alokasi padi Hazton sebanyak 44.500 hektar, dan kegiatan padi organik seluas 160 hektar. Kendala yang dihadapi oleh petani di Kalimantan Barat untuk melakukan pertanian padi organik adalah kebutuhan pupuk organik yang cukup besar per hektarnya sekitar 1030 ton.ha-1 sehingga memerlukan biaya yang tinggi dan ketersediaan pupuk organik yang kurang karena tidak semua petani memiliki ternak dan memiliki ketrampilan yang baik mengenai pembuatan pupuk organik.

Potensi perkebunan kelapa sawit yang cukup banyak di Kalimantan Barat, hingga akhir 2010 luas tanam mencapai 750.948 hektar dengan 
produksi tandan buah sebar (TBS) sebanyak 921.556 ton. Nilai guna yang potensial dari pengolahan kelapa sawit adalah limbah pabrik kelapa sawit yang dihasilkan, limbah tersebut berupa tandan kosong, lumpur dan kulit biji (kulit kernel)yang belum dimanfaat sebagai pupuk organik.

Sludge palm oil (lumpur minyak sawit) mempunyai potensi yang cukup besar untuk digunakan sebagai pupuk organik karena mengandung karbon organik 34,59\%; nitrogen total $5,51 \%$ dan $\mathrm{C} / \mathrm{N}$ 6,28; fosfor $0,24 \%$; kalium $0,52 \%$, kalsium 3,24\%, magnesium 0,36\% (Handayani dan Georgius, 2014).

Metode tanam Hazton yang baru dikembangkan di Kalimantan Barat belum memberikan bukti yang jelas tentang produktivitas gabah yang akan diperoleh. Oleh karena itu penulis ingin mengetahui metode tanam yang menghasilkan produktivitas padi yang optimal apabila dikombinasikan dengan penggunaan sludge palm oil.

\section{METODELOGI}

Penelitian dilaksanakan di Lahan Praktikum Program Studi Budidaya Tanaman Pangan Politeknik Tonggak Equator dari bulan April 2017 sampai dengan September 2017. Bahan yang digunakan dalam penelitian ini adalah sludge palm oil dan benih padi Inpara 3. Alat-alat yang digunakan antara lain alat-alat budidaya tanaman, oven, dan timbangan digital.

Penelitian ini menggunakan rancangan kelompok faktorial terdiri dari dua faktor yaitu pemberian sludge palm oil terdiri atas 5 taraf yaitu 0,10,20,30 dan 40 ton.ha ${ }^{-1}$ dan dan metode tanam yang terdiri atas 3 taraf yaitu Hazton, SRI dan konvensional. Jumlah total perlakuan adalah 15 kombinasi pelakuan, tiap perlakuan diulang lima kali sehingga diperoleh 75 satuan percobaan. Penelitian dilakukan tanpa menggunakan pupuk anorganik. Metode tanam Hazton menggunakan bibit 30 bibit per rumpun dengan umur bibit 30 hari, metode tanam SRI menggunakan 1 bibit per rumpun dengan umur bibit 12 hari, serta metode tanam konvensional menggunakan 3 bibit per rumpun dengan umur bibit 12 hari. Sludge palm oil diberikan di lubang tanam 1 minggu sebelum tanam. Penelitian ini tidak dilakukan pemupukan menggunakan pupuk anorganik.

Variabel pengamatan yang diambil adalah tinggi tanaman, jumlah anakan, jumlah malai, berat basah berangkasan batang, berat gabah kering giling (GKG), dan berat 1000 biji. Analisis data menggunakan sidik ragam, apabila sidik ragan padaa taraf 5\% terdapat pengaruh nyata maka dilanjutkan dengan uji DMRT (Duncan Multiple Range Test).

\section{III.HASIL DAN PEMBAHASAN \\ Analisa Sludge Palm Oil}

Sludge palm oil diambil dari PT. Bumi Pratama Kahtulistiwa merupakan limbah dari pengolahan CPO (Crude Palm Oil) kelapa sawit. Sebelum digunakan dilakukan pengomposan selama 3 minggu. Hasil analisa dapat dilihat pada Tabel 1. Berdasarkan hasil analisa tersebut, sludge palm oil dapat dikategorikan sebagai pupuk organik. Disebutkan dalam Jenny dan Sawadji (1999), secara tidak langsung sludge mampu meningkatkan kesuburan tanah. Bersama dengan mineral tanah, bahan sludge yang diaplikasikan berpengaruh pada sejumlah aktivitas kimia tanah.

TABEL 1. HASIL ANALISA SLUDGE PALM OIL

\begin{tabular}{lrc}
\hline Parameter Analisis & Nilai & Standar Mutu* \\
\hline pH & 6.23 & 4 s/d 9 \\
C-Organik (\%) & 43.11 & $\min 15$ \\
N-total (\%) & 4.68 & \\
C/N rasio & 9.21 & $15-25$ \\
Fosfor (\%) & 0.51 & $\min 4$ \\
Kalium (\%) & 0.49 & $\min 4$ \\
Kalsium (\%) & 0.59 & $\min 4$ \\
Magnesisum (\%) & 0.24 & \\
\hline
\end{tabular}

Keterangan * = Permentan No. 17/Permentan/S.R. 140/ 2011

\section{Analisa Tanah}

Analisa tanah (Tabel 2) menunjukkan bahwa pemberian sludge palm oil meningkatkan kandungan $\mathrm{C}$-organik, $\mathrm{N}$-total dan $\mathrm{P}$ tersedia di dalam tanah. Peningkatan tertinggi C-organik terdapat pada perlakuan $\mathrm{S}_{4} \quad\left(40\right.$ ton.ha $\left.^{-1}\right)$. Peningkatan ini terjadi akibat pemberian sludge palm oil yang termasuk/tergolong bahan organik yang dapat meningkatkan C-organik. Widhiastuti, et all. (2006) mengatakan bahwa limbah kelapa sawit yang diaplikasikan ke lahan pertanian dapat berfungsi sebagai bahan organik yang dapat meningkatkan $\mathrm{pH}$, kadar bahan organik, $\mathrm{N}$ total, $\mathrm{P}$ tersedia, $\mathrm{K}$ dan $\mathrm{Mg}$ tukar tanah.

Hasil analisis $\mathrm{pH}\left(\mathrm{H}_{2} \mathrm{O}\right)$ pada tanah yang diberikan berbagai dosis sludge palm oil, nilai $\mathrm{pH}$ tanah menurun bila dibandingkan dengan hasil analisis awal sebelum perlakuan. Namun penurunan nilai $\mathrm{pH}$ masih dalam kriteria yang sama. Rataan $\mathrm{pH}$ $\left(\mathrm{H}_{2} \mathrm{O}\right)$ akibat pemberian sludge palm oil dapat dilihat pada Tabel 1.

Menurut Irawan (2016), penurunan pH tanah akibat perlakuan bahan organik diduga karena pada proses penguraian bahan organik menghasilkan asam-asam organik, namun tidak dapat merubah kriteria status $\mathrm{pH}$ tanah yaitu tetap pada kriteria agak masam 
Emilia Farida Budi Handayani, Pamela.Pemberian Sludge Palm Oil (SPO) dan Penggunaan Metode Tanam Hazton, Sri dan Konvensional terhadap Produksi dan Hasil Padi

Pemberian sludge palm oil meningkatkan kandungan $\mathrm{N}$-total dan $\mathrm{P}$ tersedia di dalam tanah. Penambahan bahan organik meningkatkan N-total tanah karena penyediaan $\mathrm{N}$ dari sludge palm oil lebih cepat dan telah mengalami dekomposisi terlebih dahulu sebelum diberikan ke dalam tanah. Menurut Utami (2004), kandungan bahan organik mengandung banyak hara nitrogen dan laju proses terjadinya pembebasan nitrogen melalui proses mineral dari sisa-sisa bahan organik yang dibutuhkan mikroorganisme. Penambahan bahan organik dapat meningkatkan $\mathrm{P}$ tersedia di dalam tanah. Irawan (2016) menyatakan bahwa peningkatan $\mathrm{P}$ tersedia setelah diberikan bahan organik diduga karena pada proses dekomposisi menghasilkan asam-asam organik yang dapat membantu melepaskan $\mathrm{P}$ yang diikat oleh fraksi amorf (alofan) sehingga konsentrasi P-tersedia meningkat. Hal ini sejalan dengan pendapat Hastuti (2003) yang mengungkapkan bahwa hasil penguraian bahan organik menghasilkan asam humat dan fulvat sehingga $\mathrm{P}$ yang terikat dapat dilepaskan dan menjadi tersedia dalam tanah.

Semua perlakuan dalam penelitian ini memiliki kandungan Kalium yang rendah menurut kriteria penilaian sifat-sifat kimia tanah yaitu lebih kecil dari $0.2 \%$. Hal ini diduga karena tanaman cenderung mengambil unsur $\mathrm{K}$ dalam jumlah yang jauh lebih banyak dari yang dibutuhkan tetapi tidak menambah produksi sehingga jumlah kalium dalam tanah menjadi sedikit (Hardjowigeno, 2003).

\begin{tabular}{|c|c|c|c|c|c|c|c|c|c|c|c|c|c|c|}
\hline & S0 & $\begin{array}{r}\text { Sebel } \\
\text { um }\end{array}$ & $\begin{array}{l}\text { peneli } \\
\text { tian }\end{array}$ & S3 & $\mathrm{S} 4$ & $\begin{array}{l}\text { Rat } \\
\text { aan }\end{array}$ & $\begin{array}{c}\text { Kriteria } \\
\text { Sifat } \\
\text { Kimia* }\end{array}$ & S0 & $\mathrm{S} 1$ & $\begin{array}{r}\text { Sete } \\
\text { lah }\end{array}$ & $\begin{array}{l}\text { peneli } \\
\text { tian }\end{array}$ & $\mathrm{S} 4$ & $\begin{array}{l}\text { Rat } \\
\text { aan }\end{array}$ & $\begin{array}{c}\text { Kriteria } \\
\text { Sifat } \\
\text { Kimia* }\end{array}$ \\
\hline \multirow{5}{*}{$\begin{array}{l}\mathrm{pH} \\
\mathrm{C}-\text { Organik } \\
(\%)\end{array}$} & \multirow{3}{*}{6.88} & \multirow{3}{*}{7.35} & \multirow{3}{*}{7.25} & \multirow{3}{*}{7.3} & \multirow{3}{*}{7.32} & \multirow{3}{*}{7.22} & \multirow{3}{*}{ Netral } & 6.9 & \multirow{3}{*}{6.92} & \multirow{3}{*}{6.84} & \multirow{3}{*}{6.81} & \multirow{3}{*}{6.83} & 6.87 & \multirow{5}{*}{$\begin{array}{l}\text { Netral } \\
\text { Sangat } \\
\text { Tinggi }\end{array}$} \\
\hline & & & & & & & & 7 & & & & & 4 & \\
\hline & & & & & & & & 6.2 & & & & & & \\
\hline & 4.01 & 4.81 & 4.84 & 4.92 & 5.07 & 4.73 & Tinggi & 5 & 6.5 & 6.18 & 6.33 & 7.21 & 6.49 & \\
\hline & & & & & & 0.61 & & 0.6 & & & & & & \\
\hline N-total (\%) & 0.52 & 0.61 & 0.63 & 0.65 & 0.67 & 6 & Tinggi & 9 & 0.72 & 0.67 & 0.69 & 0.81 & 0.72 & Tinggi \\
\hline $\mathrm{P} 2 \mathrm{O} 5$ & 146. & 148.0 & 135.9 & 157. & 155. & 148. & Sangat & 27 & 193. & 158. & 328.8 & 210. & 232. & Sangat \\
\hline$(\mathrm{ppm})$ & 61 & 4 & 8 & 79 & 38 & 76 & tinggi & 3.5 & 55 & 54 & 8 & 28 & 95 & Tinggi \\
\hline $\mathrm{Ca}(\mathrm{cmol}$ & 25.3 & & & 32.8 & 34.2 & 30.7 & Sangat & 4.2 & & & & & & \\
\hline$(+) \mathrm{kg}^{-1)}$ & 7 & 29.74 & 31.52 & 3 & 1 & 34 & tinggi & 1 & 1.92 & 2.13 & 7.02 & 6.52 & 4.36 & Rendah \\
\hline $\mathrm{Mg}(\mathrm{cmol}$ & & & & & & 3.56 & & 0.9 & & & & & & \\
\hline$(+) \mathrm{kg}^{-1)}$ & 3.26 & 3.56 & 3.62 & 3.67 & 3.73 & 8 & Tinggi & 7 & 0.97 & 0.96 & 0.56 & 0.81 & 0.85 & Rendah \\
\hline $\mathrm{K}(\mathrm{cmol}(+)$ & & & & & & & & 0.0 & & & & & & \\
\hline $\mathrm{kg}^{-1)}$ & 0.19 & 0.21 & 0.24 & 0.24 & 0.27 & 0.23 & Rendah & 6 & 0.3 & 0.19 & 0.09 & 0.28 & 0.18 & Rendah \\
\hline $\mathrm{Na}(\mathrm{cmol}$ & & & & & & 0.32 & & & & & & & & \\
\hline$(+) \mathrm{kg}^{-1)}$ & 0.3 & 0.3 & 0.32 & 0.32 & 0.37 & 2 & Rendah & 0.1 & 0.24 & 0.26 & 0.17 & 0.4 & 0.23 & Rendah \\
\hline
\end{tabular}

Sumber: Laboratorium Kimia dan Kesuburan Tanah Fakultas Pertanian Universitas Tanjungpura, 2017

Keterangan :

*= Kriteria penilaian sifat-sifat kimia tanah Pusat Penelitian Tanah (1983) dalam Hardjowigeno (2003).

\section{Pertumbuhan dan Hasil Tanaman}

Hasil analisis statistik menunjukkan pemberian sludge palm oil dan metode tanam memberikan pengaruh interaksi yang nyata terhadap variabel pengamatan tinggi tanaman, berat kering gabah giling dan berat 1000 biji. Variabel pengamatan jumlah anakan, jumlah malai, dan berat basah berangkasan batang memberikan pengaruh yang nyata tertapi tidak terdapat interaksi di antara kedua perlakuan.

\section{Tinggi Tanaman}

Pengaruh interaksi antara pemberian sludge palm oil 40 ton.ha-1 dan metode tanam SRI memberikan rataan tinggi tanaman yang tertinggi. Sludge palm oil dapat meningkatkan pertumbuhan tanaman karena sludge palm oil dapat meningkatkan karbon organik, N-total dan $\mathrm{P}$ tersedia di dalam tanah. Menurut Siwanto et all. (2015) walaupun sebenarnya sumbangan hara N,P, dan K dari pupuk organik relatif kecil sekitar $0-10 \%$ tergantung dari mineralisasi dari pupuk organik tersebut. Hal ini berarti $40 \%$ sampai $50 \%$ hara N,P, dan K berasal dari perbaikan sifat fisik dan biologi tanah. Rasio $\mathrm{C} / \mathrm{N}$ sludge palm oil sebesar 9,21 menunjukkan bahwa mineralisasi sludge palm oil berlangsung dengan baik. Menurut Hanum (2013), efektivitas penyerapan unsur hara bahan organik juga sangat dipengaruhi oleh kadarnya di dalam tanah.

Metode SRI yang menggunakan 1 (satu) bibit per rumpun memberikan rataan tinggi tanaman tertinggi dibandingkan dengan metode tanam yang lain. Menurut Misran (2014), semakin banyak jumlah bibit yang digunakan maka tinggi tanaman cenderung lebih rendah. Hal ini dikarenakan jumlah bibit yang sedikit mengakibatkan tanaman lebih banyak menerima intensitas cahaya matahari sehingga aktifitas fotosintesa berlangsung lebih baik. 
Pengaruh interaksi tersebut diduga metode tanam yang digunakan memberikan pengaruh terhadap tinggi tanaman, apabila metode tanam yang sesuai dan didukung dengan pemberian sludge palm oil, maka akan menghasilkan tinggi tanaman yang lebih optimal.

TABEL 3. PENGARUH INTERAKSI TINGGI TANAMAN PADI DENGAN PEMBERIAN SLUDGE PALM OIL DAN METODE TANAM

\begin{tabular}{|c|c|c|c|c|}
\hline \multirow[b]{2}{*}{$\begin{array}{c}\text { Sludge Palm } \\
\text { Oil }\end{array}$} & \multicolumn{3}{|c|}{$\begin{array}{l}\text { Metode } \\
\text { Tanam }\end{array}$} & \multirow[t]{2}{*}{$\begin{array}{c}\text { Rerat } \\
\mathrm{a}\end{array}$} \\
\hline & $\begin{array}{c}\mathrm{M}_{1} \\
\text { (Hazto } \\
\mathrm{n})\end{array}$ & $\begin{array}{c}\mathrm{M}_{2} \\
(\mathrm{SRI})\end{array}$ & $\begin{array}{c}\mathrm{M}_{3} \\
\text { (Konvensional }\end{array}$ & \\
\hline $\mathrm{S}_{0}$ & $\begin{array}{c}96.0 \mathrm{a} \\
\mathrm{A}\end{array}$ & $\begin{array}{c}107.6 \mathrm{a} \\
\mathrm{A}\end{array}$ & $\begin{array}{c}107.4 \mathrm{a} \\
\mathrm{A}\end{array}$ & $\begin{array}{c}209 . \\
60\end{array}$ \\
\hline $\mathrm{S}_{1}$ & $\begin{array}{c}108.8 \mathrm{a} \\
\mathrm{A}\end{array}$ & $\begin{array}{c}107.8 \mathrm{a} \\
\mathrm{A}\end{array}$ & $\begin{array}{c}101.2 \mathrm{a} \\
\mathrm{A}\end{array}$ & $\begin{array}{c}213 . \\
87\end{array}$ \\
\hline $\mathrm{S}_{2}$ & $\begin{array}{c}103.0 \mathrm{a} \\
\mathrm{A}\end{array}$ & $\begin{array}{c}109.4 \mathrm{a} \\
\mathrm{A}\end{array}$ & $\begin{array}{c}111.4 \mathrm{a} \\
\mathrm{A}\end{array}$ & $\begin{array}{c}213 . \\
33\end{array}$ \\
\hline $\mathrm{S}_{3}$ & $\begin{array}{c}101.4 \mathrm{a} \\
\mathrm{A}\end{array}$ & $\begin{array}{c}112.2 \mathrm{a} \\
\mathrm{B}\end{array}$ & $\begin{array}{c}102.6 \mathrm{a} \\
\mathrm{A}\end{array}$ & $\begin{array}{c}216 . \\
47\end{array}$ \\
\hline $\mathrm{S}_{4}$ & $\begin{array}{c}107.6 \mathrm{a} \\
\mathrm{A}\end{array}$ & $\begin{array}{c}117.6 \mathrm{a} \\
\mathrm{B}\end{array}$ & $\begin{array}{c}108.0 \mathrm{a} \\
\mathrm{A}\end{array}$ & $\begin{array}{c}217 . \\
87\end{array}$ \\
\hline & 103.36 & 110.92 & 106.12 & \\
\hline
\end{tabular}

Keterangan: Angka yang diikuti huruf yang sama tidak berbeda nyata menurut uji lanjut jarak Duncan pada taraf nyata 5\%. Huruf kecil dibaca arah horisontal (baris) dan huruf kapital dibaca arah vertikal (kolom).

\section{Jumlah Anakan, Jumlah Malai dan Berat Basah Berangkasan Batang}

Pemberian sludge palm oil dan metode tanam memberikan pengaruh nyata terhadap jumlah anakan, tetapi tidak terjadi interaksi di antara kedua perlakuan. Tabel 2 menunjukkan bahwa pemberian sludge palm oil dengan dosis 20 ton.ha $^{-1}$ memberikan jumlah anakan tertinggi yaitu 24,80 anakan sedangkan penggunaan metode tanam SRI memberikan rataan jumlah anakan yang tertinggi yaitu 29,28 anakan.

Penggunaan metode tanam SRI memberikan rataan berat basah berangkasan batang yang tertinggi yaitu 396,77 g tidak berbeda nyata dengan penggunaan metode tanam konvensional yaitu 349,61 g tetapi berbeda nyata dengan penggunaan metode tanam Hazton yaitu 283,64 g.

Pemberian sludge palm oil dan metode tanam memberi pengaruh nyata terhadap rataan jumlah malai tetapi tidak terdapat interaksi pada kedua perlakuan tersebut. Pemberian sludge palm oil sebanyak 30 ton.ha-1 memberikan rataan jumlah malai yang tertinggi yaitu 43.13 malai dan penggunaan metode tanam SRI memberikan beda sangat nyata dari metode tanam Hazton dan konvensional.

Pemberian sludge palm oil memberikan rataan jumlah anakan yang berpengaruh nyata dibandingkan tanpa diberi sludge palm oil. Menurut Siregar (2007) sludge yang dihasilkan dari pengolahan minyak sawit (PMS) mengandung unsur hara nitrogen, fosfor, kalium, magnesium, dan kalsium yang cukup tinggi sehingga dapat digunakan sebagai pupuk organik.

Metode tanam SRI memberikan rataan jumlah anakan yang tertinggi dibanding metode tanam konvensional dan Hazton diduga metode tanam ini menggunakan satu bibit per rumpun dan umur bibit 12 hari dimana menurut hasil penelitian Napisah dan Rini (2014) perlakuan umur bibit 15 HSS memberikan hasil tertinggi dengan rata-rata jumlah anakan 13,07 btg/rpn dan berbeda nyata dengan umur bibit 10 HSS yaitu 9,90 btg/rumpun. Hal tersebut disebabkan oleh kondisi perakaran di persemaian yang makin kuat dan dalam sehingga waktu pemindahan mengalami kerusakan cukup berat. Jumlah anakan yang produktif yang banyak selain tinggi tanaman padi. Keadaan faktor genetis memberikan pengaruh yang hampir sama pula terhadap tinggi tanaman padi (Hermawati T., 2009). Selanjutnya Gani (2003) menyatakan bahwa penggunaan bibit padi sawah dengan umur yang relative muda (umur 12-15 HSS) akan membentuk anakan baru yang lebih seragam ada aktif serta berkembang lebih baik karena bibit yang lebih muda mampu beradaptasi dengan lingkungan yang baru setelah tanaman dipindah.

Rataan berat basah berangkasan batang pada sistem tanam SRI lebih tingi dibanding kedua sistem tanam yang lain diduga karena sistem tanam ini menggunakan bibit muda dan jumlah bibit yang sedikit. Menurut Ali at all. (2017), penggunaan 1 bibit per lubang tanam pada awalnya menunjukkan pertumbuhan yang lambat akan tetapi mingguminggu selanjutnya mulai berkembang engan pesat dan bahkan dapat melampaui 2 dan 3 bibit per lubang tanam. Hal ini terjadi karena tidak terjadi persaingan unsur hara dan sinar matahari sehingga terjadi pertambahan jumlah anakn per urmpun yang meningkatkan berat basah berangkasan.

Rataan jumlah malai pada penggunaan metode tanam SRI tertinggi dibandingkan metode tanam yang lain karena Metode tanam SRI menggunakan 1 bibit sehingga kepadatan 
Emilia Farida Budi Handayani, Pamela.Pemberian Sludge Palm Oil (SPO) dan Penggunaan Metode Tanam Hazton, Sri dan Konvensional terhadap Produksi dan Hasil Padi

populasi per rumpun rendah. Menurut Misran (2014), metode tanam yang menggunakan bibit yang banyak akan mengurangi jumlah malai. Dari Tabel 5 terlihat perlakuan metode tanam SRI yang menggunakan bibit 1 batang per rumpun memberikan jumlah malai cenderung lebih baik dibanding perlakuan lainnya. Hal yang sama juga didapatkan dari hasil penelitian Abdullah (2004) pada varietas Cisokan. Menurut Musa (2000), bertanam padi sawah secara tanam pindah dengan bibit muda (umur 10-15 hss) dan jumlah bibit kurang dari 5 batang per rumpun dapat meningkatkan mutu gabah yang dihasilkan. Sedangkan Balitpa (2002) menyatakan bahwa penanaman bibit muda (umur 10-15 hss) dengan jumlah bibit tunggal (1 batang per rumpun) akan memberikan pertumbuhan yang lebih baik dan mampu beradaptasi serta dapat menghemat pemakaian benih sampai $50 \%$

Tabel 4. Pengaruh Pemberian SLUdGe Palm oil Dan PenggunaAn metode tanam terhadap Jumlah anaKan, JUmlah MALAI, DAN BERAT BASAH BERANGKASAN BATANG

\begin{tabular}{lccc}
\hline \multicolumn{1}{c}{ Perlakuan } & Jumlah Anakan & Jumlah Malai & $\begin{array}{c}\text { Berat basah berangkasan } \\
\text { batang }\end{array}$ \\
\hline \multicolumn{1}{c}{ Sludge Palm Oil } & & & \\
$\mathrm{S}_{0}=0$ ton.ha-1 & $14.87 \mathrm{a}$ & $37.00 \mathrm{a}$ & $329.83 \mathrm{a}$ \\
$\mathrm{S}_{1}=10$ ton.ha-1 & $19.93 \mathrm{~b}$ & $34.93 \mathrm{a}$ & $346.10 \mathrm{a}$ \\
$\mathrm{S}_{2}=20$ ton.ha-1 & $24.80 \mathrm{~b}$ & $42.60 \mathrm{~b}$ & $332.54 \mathrm{a}$ \\
$\mathrm{S}_{3}=30$ ton.ha-1 & $24.40 \mathrm{~b}$ & $43.13 \mathrm{~b}$ & $351.23 \mathrm{a}$ \\
$\mathrm{S}_{4}=40$ ton.ha-1 & $24.07 \mathrm{~b}$ & $40.40 \mathrm{~b}$ & $357.00 \mathrm{a}$ \\
\hline Metode Tanam & & & \\
$\mathrm{M}_{1}$ (Hazton) & $8.00 \mathrm{a}$ & $17.36 \mathrm{a}$ & $283.64 \mathrm{a}$ \\
$\mathrm{M}_{2}$ (SRI) & $29.28 \mathrm{~b}$ & $63.56 \mathrm{c}$ & $396.77 \mathrm{~b}$ \\
$\mathrm{M}_{3}$ (konvensional) & $27.56 \mathrm{~b}$ & $37.92 \mathrm{~b}$ & $349.61 \mathrm{~b}$ \\
\hline
\end{tabular}

Keterangan : angka-angka yang diikuti huruf yang sama pada kolom yang sama tidak berbeda nyata berdasarkan uji Duncan pada $\alpha=5 \%$

\section{Berat Gabah Kering Giling}

Berat gabah kering giling (GKG) berdasarkan analisis menunjukkan bahwa perlakuan pemberian sludge palm oil dan metode tanam memberikan pengaruh interaksi yang nyata. Rataan berat gabah kering giling (GKG) yang tertinggi terdapat dari pemberian sludge palm oil sebanyak 10 ton.ha ${ }^{-1}$ dan metode tanam SRI. Hal ini menunjukkan bahwa pemberian sludge palm oil 10 ton.ha ${ }^{-1}$ dengan menggunakan metode tanam SRI secara bersamaan dapat memberikan rataan gabah kering giling yang tertinggi.

Pemberian sludge palm oil dengan menggunakan metode tanam SRI memberikan pengaruh nyata terhadap rataan berat kering giling gabah dibandingkan pemberian sludge palm oil dengan menggunakan metode tanam Hazton dan konvensional. Sludge palm oil yang mengandung unsur hara yang diperlukan sehingga dapat meningkatkan berat kering giling gabah. Pengaruh interaksi berat Gabah Kering Giling (GKG) tanaman padi dengan pemberian sludge palm oil dan metode tanam dapat dilihat pada gambar 2.

Metode tanam Hazton yang menggunakan 30 bibit per rumpun memberikan rataan berat gabah kering giling terendah dibanding metode SRI dan konvensional. Penggunaan bibit yang banyak diduga dapat menimbulkan persaingan di antara tanaman sehingga pertumbuhan dan perkembangan terganggu. Misran (2014) menyatakan bahwa semakin banyak jumlah bibit yang ditanam maka secara nyata akan mengurangi panjang malai, persentase gabah hampa meningkat, dan menurunkan bobot biji.

TABel 5. Pengaruh interaksi berat Gabah Kering

GILING (GKG) TANAMAN PADI DENGAN PEMBERIAN

\begin{tabular}{|c|c|c|c|c|}
\hline \multirow[t]{2}{*}{$\begin{array}{c}\text { Sludge } \\
\text { Palm Oil }\end{array}$} & & $\begin{array}{r}\text { Meto } \\
\text { de }\end{array}$ & Tanam & \multirow[t]{2}{*}{$\begin{array}{c}\text { Rera } \\
\text { ta }\end{array}$} \\
\hline & $\begin{array}{c}\mathrm{M}_{1} \\
\text { (Hazt } \\
\text { on) }\end{array}$ & $\begin{array}{c}\mathrm{M}_{2} \\
\text { (SRI) }\end{array}$ & $\begin{array}{c}\mathrm{M}_{3} \\
\text { (Konvensi } \\
\text { onal) }\end{array}$ & \\
\hline $\mathrm{S}_{0}$ & $\begin{array}{c}4.81 \mathrm{a} \\
\mathrm{A}\end{array}$ & $\begin{array}{c}5.20 \\
\mathrm{~b} \\
\mathrm{~A}\end{array}$ & $\begin{array}{c}4.87 \mathrm{a} \\
\mathrm{A}\end{array}$ & 4.96 \\
\hline$S_{1}$ & $\begin{array}{c}5.51 \mathrm{a} \\
\mathrm{B}\end{array}$ & $\begin{array}{c}5.95 \\
\mathrm{~b} \\
\mathrm{~B}\end{array}$ & $\begin{array}{c}5.48 \mathrm{a} \\
\mathrm{B}\end{array}$ & 5.65 \\
\hline $\mathrm{S}_{2}$ & $\begin{array}{c}5.14 \mathrm{a} \\
\mathrm{A}\end{array}$ & $\begin{array}{c}5.76 \\
\mathrm{~b} \\
\mathrm{~B}\end{array}$ & $\begin{array}{c}5.26 \mathrm{a} \\
\mathrm{B}\end{array}$ & 5.39 \\
\hline $\mathrm{S}_{3}$ & $\begin{array}{c}5.10 \mathrm{a} \\
\mathrm{A}\end{array}$ & $\begin{array}{c}5.06 \\
\mathrm{a} \\
\mathrm{A}\end{array}$ & $\begin{array}{c}5.36 \mathrm{a} \\
\mathrm{B}\end{array}$ & 5.17 \\
\hline $\mathrm{S}_{4}$ & $\begin{array}{c}5.08 \mathrm{a} \\
\mathrm{A}\end{array}$ & $\begin{array}{c}5.20 \\
\mathrm{a} \\
\mathrm{A}\end{array}$ & $\begin{array}{c}5.40 \mathrm{a} \\
\mathrm{B}\end{array}$ & 5.22 \\
\hline & 5.13 & 5.43 & 5.27 & \\
\hline
\end{tabular}

Keterangan: Angka yang diikuti huruf yang sama tidak berbeda nyata menurut uji lanjut jarak Duncan pada taraf nyata 5\%. Huruf kecil dibaca arah horisontal (baris) dan huruf kapital dibaca arah vertikal (kolom). 


\section{Berat 1000 Biji}

Pemberian sludge palm oil 20 ton.ha ${ }^{-1}$ dan metode tanam SRI memberikan rataan tertinggi untuk berat 1000 biji. Kombinasi ke dua perlakuan ini menghasilkan rataan tertinggi untuk berat 1000 biji dikarenakan sludge palm oil memberikan unsur hara yang cukup untuk perkembangan tanaman padi dan penggunaan metode tanam SRI yang menggunakan bibit satu lubang per rumpun dengan umur bibit 12 hari mampu menghasilkan rataan berat 1000 biji yang tertinggi.

Balitpa (2002) menyatakan bahwa penanaman padi menggunakan bibit muda (umur 1015 hss) dengan jumlah bibit tunggal (1 batang per rumpun) akan memberikan pertumbuhan yang lebih baik dan mampu beradaptasi serta dapat menghemat pemakaian benih sampai $50 \%$.

Penerapan budidaya dengan menggunakan metode tanam SRI, yakni dengan menggunakan umur bibit yang muda bertujuan agar tidak terjadi persaingan di antara akar tanaman yang dapat menghambat pertumbuhan tanaman. Bibit yang dipindahkan dan ditanam satu-satu memiliki ruang untuk menyebar dan memperdalam perakaran sehingga tidak bersaing terlalu ketat untuk memperoleh ruang tumbuh akar, cahaya atau nutrisi dalam tanah (Usman et all. 2014).

TABel 6. Pengaruh interaksi Berat 1000 BiJi tanAman PADI DENGAN PEMBERIAN SLUDGE PALM OIL DAN METODE

\begin{tabular}{|c|c|c|c|c|}
\hline \multirow{3}{*}{$\begin{array}{c}\text { Sludge } \\
\text { Palm Oil }\end{array}$} & \multicolumn{3}{|c|}{ TANAM } & \multirow{3}{*}{$\begin{array}{c}\text { Rera } \\
\text { ta }\end{array}$} \\
\hline & \multicolumn{2}{|c|}{$\begin{array}{r}\text { Meto } \\
\text { de }\end{array}$} & \multirow{2}{*}{$\begin{array}{c}\text { Tanam } \\
\mathrm{M}_{3} \\
\text { (Konven } \\
\text { sional) }\end{array}$} & \\
\hline & $\begin{array}{c}\mathrm{M}_{1} \\
\text { (Hazto } \\
\mathrm{n})\end{array}$ & $\begin{array}{c}\mathrm{M}_{2} \\
(\mathrm{SRI})\end{array}$ & & \\
\hline $\mathrm{S}_{0}$ & $\begin{array}{c}17.91 \mathrm{a} \\
\mathrm{A}\end{array}$ & $\begin{array}{c}19.52 \\
\mathrm{a} \\
\mathrm{A}\end{array}$ & $\begin{array}{c}18.91 \mathrm{a} \\
\mathrm{A}\end{array}$ & $\begin{array}{c}18.7 \\
8\end{array}$ \\
\hline $\mathrm{S}_{1}$ & $\begin{array}{c}20.04 \mathrm{a} \\
\mathrm{A}\end{array}$ & $\begin{array}{c}23.62 \\
\mathrm{~b} \\
\mathrm{~B}\end{array}$ & $\begin{array}{c}21.08 \mathrm{~b} \\
\mathrm{~A}\end{array}$ & $\begin{array}{c}21.5 \\
8\end{array}$ \\
\hline $\mathrm{S}_{2}$ & $\begin{array}{c}21.35 \\
\mathrm{~b} \\
\mathrm{~A}\end{array}$ & $\begin{array}{c}24.96 \\
\mathrm{~b} \\
\mathrm{~B}\end{array}$ & $\begin{array}{c}19.81 \mathrm{a} \\
\mathrm{A}\end{array}$ & $\begin{array}{c}22.0 \\
4\end{array}$ \\
\hline $\mathrm{S}_{3}$ & $\begin{array}{c}20.43 a \\
\text { A }\end{array}$ & $\begin{array}{c}22.57 \\
\mathrm{a} \\
\mathrm{B}\end{array}$ & $\begin{array}{c}20.16 \mathrm{a} \\
\mathrm{A}\end{array}$ & $\begin{array}{c}21.0 \\
5\end{array}$ \\
\hline $\mathrm{S}_{4}$ & $\begin{array}{c}19.90 \mathrm{a} \\
\mathrm{A}\end{array}$ & $\begin{array}{c}23.36 \\
\mathrm{~b} \\
\mathrm{~B} \\
\end{array}$ & $\begin{array}{c}20.86 \\
\text { A }\end{array}$ & $\begin{array}{c}21.3 \\
7\end{array}$ \\
\hline & 19.93 & 22.81 & 20.16 & \\
\hline
\end{tabular}

Keterangan: Angka yang diikuti huruf yang sama tidak berbeda nyata menurut uji lanjut jarak Duncan pada taraf nyata 5\%. Huruf kecil dibaca arah horisontal (baris) dan huruf kapital dibaca arah vertikal (kolom)
Umur pindah bibit yang lebih muda akan menghindari stagnasi bibit dilapangan akibat transplanting (pindah bibit) dan juga merupakan upaya optimalisasi dari tanaman padi agar mencapai pertumbuhan anakan yang eksponensial atau berlipat ganda (Kasim, 2004), sehingga anakan pertama akan tumbuh pada kondisi terbaik untuk membentuk tanaman dengan rumpun yang besar. Rumpun yang besar akan meningkatkan jumlah anakan produktif yang menghasilkan malai dalam jumlah yang cukup besar sehingga berat 1000 biji juga akan meningkat. Hasil penelitian dari Porong (2012) juga menyatakan bahwa umur semai 15 hari adalah tepat untuk pindah tanam karena dapat meningkatkan bobot 1000 biji.

\section{KESIMPULAN}

1. Pemberian sludge palm oil dan metode tanam memberikan interaksi yang nyata untuk variabel pengamatan tinggi tanaman, berat kering gabah dan berat 1000 biji. Memberikan pengaruh nyata untuk jumlah anakan, jumlah malai dan berat basah berangkasan batang tetapi tidak ada interaksi yang nyata.

2. Perlakuan $\mathrm{S}_{4}$ dan $\mathbf{M}_{2}$ memberikan rataan tinggi tanaman tertinggi, perlakuan $\mathrm{S}_{1} \mathrm{M}_{2}$ memberikan rataan tertinggi untuk berat kering gabah serta per;akuan $\mathrm{S}_{2} \mathrm{M}_{2}$ memberikan rataan tertinggi untuk berat 1000 biji.

\section{UCAPAN TERIMA KASIH}

Terima kasih disampaikan kepada Direktorat Jenderal Pendidikan Tinggi, Kementerian Pendidikan dan Kebudayaan RI yang telah mendanai penelitian ini melalui Program Dosen Pemula Tahun2017 dengan nomor kontrak: 1080/K 11.A/KM/2017, tanggal 27 April 2017

\section{DAFTAR PUSTAKA}

[1] Ali M., Abdullah H., Nurlina. 2017. Perbedaan jumlah bibit per lubang tanam terhadap pertumbuhan dan hasil tanaman padi (Oryza sativa L.) dengan menggunakan metode The System Rice Intensification. J. Agrotech Sience (3): 1-21

[2] Balitpa. 2002. Pengelolaan tanaman terpadu. Inovasi sistem produksi padi sawah irigasi. Leaflet Balai Penelitian Tanaman Padi Sukamandi Jawa Bara[3] Gani, A. 2003. Sistem Intensifikasi Padi (System of Rice Intensification). Pedoman Praktis Bercocok Tanam Padi Sawah dengan Sistem SRI. 6 hal.

[4] Hanum C. 2013. Pertumbuhan,Hasil, dan Mutu Biji Kedelei dengan Pemberian Pupuk Organik dan Fosfor. J. Agron. Indonesia. 41 (3) : 209-214.

[5] Hastuti (2003) Pengaruh berbagai jenis bahan amelioran terhadap pertumbuhan dan hasil tanaman sorgum di Jawa Timur. http://repository.ipb.ac.id/bitstream/handle/20IV A93atr. pdf. Diakses 9 Desember 2013. Munir, Moch. 1996. Tanah-Tanah Utama. 
Emilia Farida Budi Handayani, Pamela.Pemberian Sludge Palm Oil (SPO) dan Penggunaan Metode Tanam Hazton, Sri dan Konvensional terhadap Produksi dan Hasil Padi

[6] Handayani E.F.B., Georgius. 2014. interaksi sludge palm oil dan jarak tanam jajar legowo terhadap pertumbuhan dan produksi jagung hibrida varietas Bisi-2. J. Agripura (8): 1.1074-1079

[7] Hermawati, T. 2009. Keragaman padi varietas indragiri pada perbedaan umur bibit dengan metode SRI (System Of Rice Intensification). J. Percikan : Vol.99 Edisi April 2009.

[8] Hardjowigeo S. 2003. Ilmu tanah. Cetakan kelima. Akademika Pressindo. Jakarta

[9] Irawan A., Yadi J., Zuraida. 2016. Pengaruh pemberian bahan organik terhadap perubahan sifat kimia andisol, pertumbuhan dan produksi gandum (Triticum eastivum L.). J. Kawista 1(1):1-9

[10] Jenny, M.U \& E. Suwadji. 1999. Pemanfaatan limbah minyak sawit (sludge) sebagai pupuk tanaman dan media jamur kayu. BATAN, Bogor.

[11] Kasim, M. 2004. Manajemen penggunaan air: meminimalkan penggunaan air untuk meningkatkan produksi padi sawah melalui sistem intensifikasi padi (The System of Rice intensification-SRI). Pidato Pengukuhan Sebagai Guru Besar Unand. Padang 2004.

[12] Laboratorium Kimia dan Kesuburan Tanah. 2017. Hasil analisis tanah. Fakultas Pertanian. Universitas Tanjungpura. Pontianak.

[13] Misran. 2014. Efisiensi penggunaan jumlah bibit terhadap pertumbuhan dan produksi padi sawah. $J$. Penelitian Pertanian Terapan Vol.14 (1): 39-43.

[14] Napisah K, Rina D. N. 2014. Pengaruh umur bibit terhadap produktivitas padi varietas Inpari 17. Hal 127-132. Dalam Prosiding Seminar Nasional Inovasi Teknologi Pertanian Spesifik Lokasi. Banjarbaru 6-7 Agustus 2014

[15] Porong V.I., 2012. Perbedaan umur bibit terhadap pertumbuhan dan produksi padi sawah (Oryza sativa L). J. Eugenia. (10) : 35-38

[16] Siwanto T. Sugiyanta. Maya M., 2015. Peran pupuk organik dalam peningkatan efisiensi pupuk anorganik pada padi sawah (Oryza sativa L.). J. Agron Indonesia 43 (1) : 8-14.

[17] Utami, S.M.H. 2004. Sifat kimia andisol pada pertanian organik dan anorganik. J. Ilmu Tanah. Skripsi. Institut pertanian Bogor.

[18] Usman Z.,Usman M., Adrianton. 2014. Pertumbuhan dan hasil tanaman padi (Oryza sativa L.) pada berbagai umur semai dengan teknik budidaya SRI (System of Rice Intensification). e-J. Agrotekbis 2 (1) : 32-37.

[19] Widhiastuti, R ., D. Suryanto., Mukhlis dan H. Wahyuningsih. 2006. Pengaruh pemanfaatan limbah cair pabrik pengolahan kelapa sawit sebagai pupuk terhadap biodiversitas tanah. J. Ilmiah Pertanian Kultura 41(1). 